\title{
Strategi Regulasi Emosi Kognitif dan Pola Asuh Orangtua pada Anak yang Menjalani Kemoterapi
}

\author{
Siti Yuyun Rahayu Fitri, Windy Rakhmawati \\ Fakultas Keperawatan Universitas Padjadjaran \\ E-mail: sitiyuyunrahayu@gmail.com
}

\begin{abstract}
Abstrak
Penelitian sebelumnya telah melihat kaitan antara regulasi emosi pada anak yang sehat dengan pola asuh orangtuanya, namun belum jelas gambaran tentang regulasi emosi pada anak yang sakit kronis dan pola asuh yang diterimanya. Penelitian ini bertujuan untuk melihat gambaran strategi regulasi emosi kognitif yang digunakan oleh anak berusia 9-11 tahun dengan kanker yang menjalani kemoterapi dan perbedaan individunya yang terdiri dari pola asuh yang didapat dari orangtuanya serta jenis kelamin anak. Jenis penelitian ini adalah deskriptif kuantitatif. Teknik sampling menggunakan accidental sampling dan didapatkan sampelsebanyak42orang(21 anakdan21 orangtua). InstrumenmenggunakanCERQ-k(CognitiveEmotionRegulation Questionnaire-kids) dan PAQ-R (Parental Authority Questionnaire-revised). Analisis data menggunakan skor mean. Hasil menunjukkan bahwa strategi regulasi emosi yang sering digunakan oleh anak adalah planning, rumination, dan putting into perspective. Perbandingan jenis kelamin sampel berimbang. Kemudian pola asuh orangtua yang sering dilakukan menunjukkan secara berturut-turut adalah tipe autoritatif, autoritarian, dan permisif. Berdasarkan hasil penelitian dapat disimpulkan bahwa regulasi emosi yang dilakukan oleh anak dengan kanker yang melakukan kemoterapi cukup adaptif, sedangkan pola asuh orangtua yang diberikan masih kurang efektif.
\end{abstract}

Kata kunci: Anak, kanker, pola asuh, regulasi emosi.

\section{Regulation Strategy of The Cognitive Emotion and Parenting Approaches in Children with Chemotherapy}

\begin{abstract}
The previous study was inquired the correlation between emotion regulations in healthy children and the parenting process. On the other hand, the emotion regulations in children with chronic diseases were little known. The aim of this quantitative descriptive study was to understand the strategic regulation of cognitive emotion that was used by children aged 9-11 years with chemotherapy, and to explore the individual parenting process based on genders. Samples were chosen using the accidental sampling technique. The samples were 21 children and 21 parents. Data were collected using Cognitive Emotion Regulation Questionnaire for kids (CERQ-k) and Parental Authority Questionnaire-revised (PAQ-R). Mean score were conducted to analyses data. Results showed that 'planning' was the most strategic used by children, followed by 'rumination' and 'putting into perspective'. The result also described that the number of samples was balance in sex. Parents used authoritative, authoritarian, and permissive approaches in parenting. In conclusion, the emotion regulation of children with chemotherapy was adaptive and the parenting approach was ineffective.
\end{abstract}

Key words: Cancer, children, emotion regulations, parenting. 
Siti Yuyun Rahayu Fitri : Strategi Regulasi Emosi Kognitif dan Pola Asuh Orangtua pada Anak

\section{Pendahuluan}

Berbagai penelitian yang dilakukan sebelumnya menyimpulkan bahwa regulasi emosi memengaruhi kondisi fisik individu (Salovey, 2001., Gross, 2007., Sapolsky, 2007). Strategi regulasi emosi antecedent focus dalam konteks situasi yang penuh stres dapat menurunkan relevansi emosionalnya, menurunkan kecenderungan teraktivasinya emosi, mengarahkan pada sedikitnya perasaan subjektif, tanda ekspresi emosi negatif berkurang, tidak terjadi peningkatan aktivasi saraf parasimpatis sehingga tidak terjadi keluhan somatik, dan peningkatan denyut jantung (Gross, 2007). Oleh karena itu, peran regulasi emosi menjadi penting pada individu dalam meningkatkan kondisi fisik (Sarafino, 2006). Menurut Middendorp (2005), gaya regulasi emosi yang membuat rileks sistem saraf (neural) dapat menurunkan keluhan dalam aspek kesehatan. Dalam penelitian potong lintangnya ditemukan bahwa terdapat hubungan yang moderat antara regulasi emosi dengan fungsi neuroendocrine. Selain itu menurut Kiecolt (2002), regulasi emosi yang baik seperti memiliki hubungan personal yang dekat sebagai upaya mengurangi emosi negatif dapat meningkatkan fungsi endokrin. Sebaliknya, emosi negatif dapat mengakibatkan kodisi infeksi memanjang dan lamanya waktu perbaikan luka.

Masalah psikologis berupa emosi sering muncul pada pasien yang dirawat di rumah sakit terutama yang membutuhkan waktu perawatan lama. Kanker merupakan kondisi sakit yang membutuhkan proses pengobatan yang lama. Kanker pada anak merupakan kondisi yang menimbulkan emosi baik pada anak maupun keluarga. Kemampuan regulasi emosi pada anak dipengaruhi oleh tingkat perkembangannya (Holodynski \& Fridelmeier, 2005; Santrock, 2008; \& Mc Caffrey, 2006). Di Indonesia, kemampuan regulasi emosi pada anak leukemia lebih dilakukan secara interpersonal, artinya didukung oleh pihak eksternal pasien terutama ibu dan keluarga (Fitri, Atmodiwirji, \& Wilman, 2011). Kemudian menurut Matsumoto, Yoo, \& Nakagawa (2008), dengan dimediasi oleh nilai subjektif dan sikap, seseorang yang berada pada kultur kolektif mempunyai dukungan interdependen yang kuat. Hal ini mempunyai implikasi bahwa jika seseorang menghadapi emosi, ia akan mendekat (engagement) dan mencari dukungan sosial. Hal ini memungkinkan seseorang memiliki bentuk regulasi interpersonal yang kuat. Sebaliknya pada kultur individual atau independent, seseorang cenderung relatif menjauh (disengagement) dari peran sosial. Hal ini memungkinkan seseorang lebih cenderung melakukan regulasi secara intrapersonal. Mengingat kanker pada anak juga membutuhkan pengobatan dalam waktu yang lama, maka pasien anak perlu mempunyai kemampuan secara intrapersonal yang seimbang dalam melakukan regulasi emosi.

Garnefski, Kraaij, dan Spinhoven, (2007) menyatakan bahwa strategi regulasi emosi secara kognitif berperan dalam masalah kesehatan pasien berusia remaja. Seseorang yang memiliki strategi positive reappraisal memiliki sedikit masalah kesehatan. Belum ada penelitian tentang strategi regulasi emosi terkait kondisi kesehatan fisik pada individu yang berusia lebih kecil. Holodynski and Fridelmeier (2005) menyatakan anak usia sekolah sudah dapat mengembangkan regulasi emosi secara intrapersonal yaitu mampu mandiri melakukan regulai emosi. Selain itu Garnefski, dkk. (2007) menyatakan bahwa anak usia 9-11 tahun sudah mampu melakukan regulasi emosi secara kognitif. Regulasi emosi kognitif juga menunjukkan tipe yang berbeda pada jenis kelamin yang berbeda (Garnefski, dkk., 2007). Kemudian Gross (2007) menyatakan bahwa pola asuh orang tua berperan dalam terbentuknya strategi regulasi emosi yang dipilih anak. Berdasarkan pemaparan tersebut, tujuan dari penelitian ini untuk melihat strategi regulasi emosi kognitif anak usia sekolah usia 9-11 tahun dan pola asuh dari orangtuanya.

\section{Metode Penelitian}

Penelitianinimenggunakanmetodedeskriptif, yang bertujuan untuk mengidentifikasi strategi regulasi emosi yang sering digunakan oleh anak usia sekolah dengan kanker yang sedang menjalani kemoterapi dan pola asuh orangtua.

Populasi dalam penelitian ini adalah 
Siti Yuyun Rahayu Fitri : Strategi Regulasi Emosi Kognitif dan Pola Asuh Orangtua pada Anak

seluruh anak usia sekolah yang berusia 9-11 tahun dengan kanker yang menjalani kemoterapi dan orangtuanya di rumah sakit pemerintah yang menyediakan layanan kemoterapi. Teknik sampling yang digunakan adalah accidental sampling, dan didapatkan sampel sebanyak 42 orang yang terdiri dari 21 anak dan 21 orangtua. Variabel dalam penelitian ini adalah regulasi emosi anak usia 9-11 tahun dengan kanker yang menjalani kemoterapi, yang terdiri dari subvariabel: self blame, other blame, acceptance, planning, positive refocusing, rumination, positive reappraisal, putting into perspective, dan catastrophizing.

Berikut ini adalah penjelasan dari subvariabel tersebut: (1) Self blame adalah jenis regulasi emosi yang mengacu pada pemikiran yang menganggap apa yang dialaminya sebagai akibat dari kesalahan dirinya sendiri, (2) Other blame: berarti individu menganggap apa yang dialaminya sebagai kesalahan orang lain, (3) Acceptance: menerima apa yang dialami dan menerima pula bahwa dirinya memang berada dalam pengalaman itu, (4) Planning: pemikiran tentang langkah yang akan diambil dan bagaimana mengatasi peristiwa negatif, (5)
Positive refocusing: berpikir tentang isu kegembiraan daripada memikirkan peristiwa aktual yang dialami, (6) Rumination: berpikir tentang perasaan dan pemikiran yang berkaitan dengan peristiwa negatif dan merenungkan apa yang dialami, (7) Positive reappraisal: berpikir untuk mengaitkan kejadian yang dialami dengan makna positif, (8) Putting intoperspective: berpikir untuk menurunkan keseriusan peristiwa negatif yang dialami, (9) Catastrophizing: menekankan pada pemikiran yang eksplisit tentang ketakutan dari apa yang dialami, atau dengan kata lain sebagai pemikiran yang beranggapan bahwa peristiwa yang dialaminya merupakan sesuatu yang sangat buruk dan dirinya adalah yang paling menderita.

Variabel yang lain dalam penelitian ini adalah pola asuh orangtua, yang terdiri dari tipe: autoritatif, autoritarian, dan permisif. Teknik pengumpulan data dengan menggunakan kuesioner untuk menilai regulasi emosi menggunakan Cognitive Emotion Regulation Quesioner kids (CERQ-k) dari Garnefski, dkk. (2007). Kuesioner ini terdiri dari sembilan subskala yang masing-masing terdiri dari empat item. Sehingga keseluruhan kuesioner terdiri dari 36 item. Partisipan diminta mengisi

Tabel 1 Karekteristik Demografi Responden

\begin{tabular}{lcc}
\hline \multicolumn{1}{c}{ Karekteristik Anak } & Frekuensi (n) & Persentase (\%) \\
\hline Usia (Tahun) & 5 & 24 \\
9 & 1 & 5 \\
10 & 2 & 9 \\
11 & 8 & 38 \\
12 & 5 & 24 \\
13 & & \\
Jenis Kelamin & 10 & 48 \\
Laki-laki & 11 & 52 \\
Perempuan & & \\
Anak ke & 4 & 19 \\
1 & 5 & 24 \\
2 & 9 & 43 \\
3 & 2 & 9 \\
4 & 1 & 5 \\
5 & & \\
Suku Bangsa & 20 & 55 \\
Sunda & 1 & 5 \\
Jawa & & \\
\hline
\end{tabular}


Siti Yuyun Rahayu Fitri : Strategi Regulasi Emosi Kognitif dan Pola Asuh Orangtua pada Anak

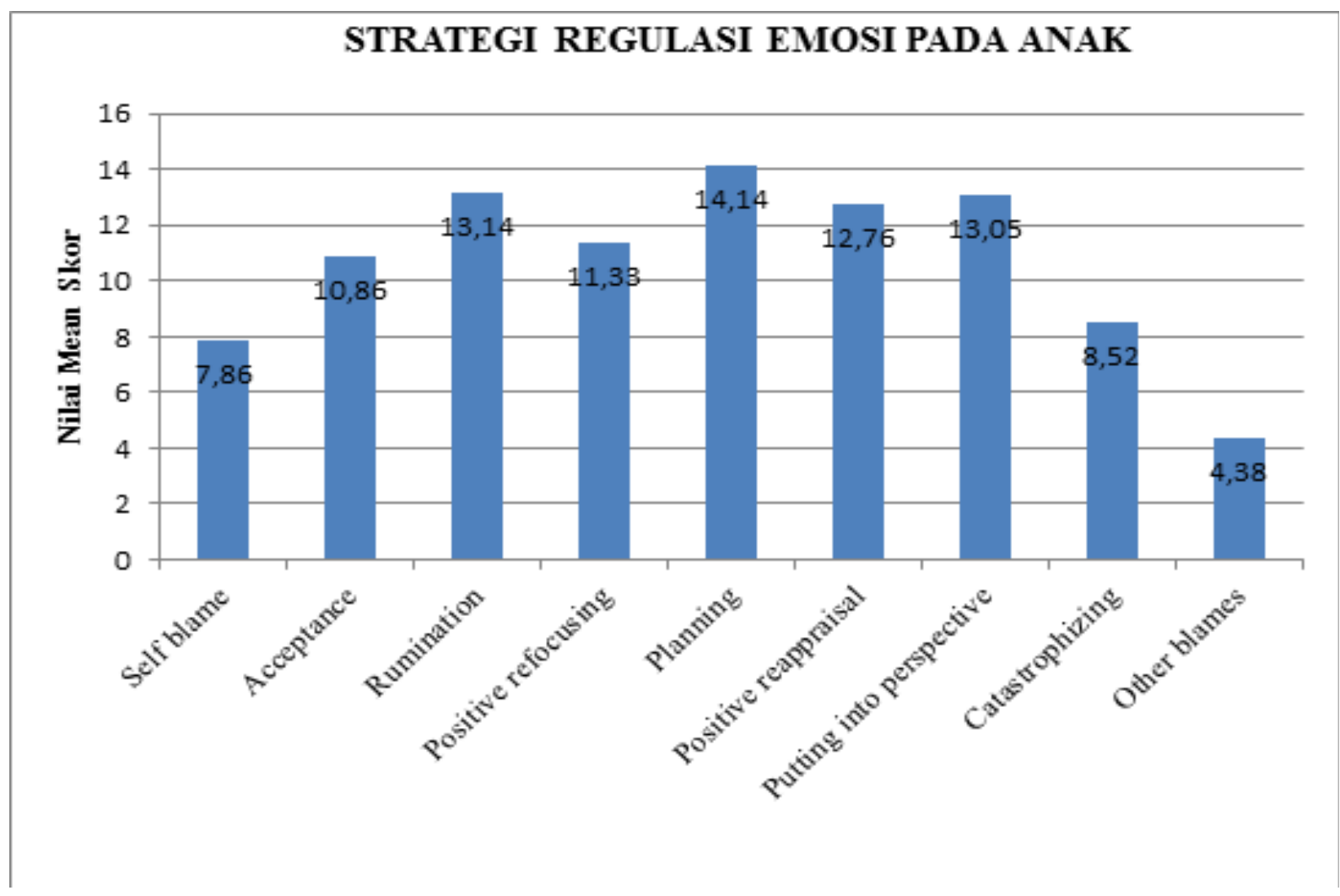

Diagram 1 Strategi Regulasi Emosi Kognitif Anak dengan Kanker yang menjalani Kemoterapi

kuesioner tentang regulasi emosi dengan CERQ-k, yang terdiri dari sembilan subskala yang masing-masing terdiri dari empat item, yang menggunakan rating scale 1 sampai 5, dimana 1 bermakna (hampir) tidak pernah dan 5 (hampir) selalu. Maka masingmasing subskala minimal bernilai empat dan maksimal 20. Dari skor yang dikumpulkan, ditentukan kategori regulasi emosi yang sering dilakukan dan yang jarang dilakukan dengan analisis nilai mean.

Kuesioner untuk pola asuh menggunakan PAQ-R (Parental Authority QuestionnaireRevised) dari Reitman (2002), yang terdiri dari 30 item pernyataan yang kemudian dikelompokkan menjadi tipe autoritatif, autoritarian, dan permisif.

Analisis data untuk variabel regulasi emosi dan pola asuh dilakukan dengan menggunakan skor mean, artinya bila skor responden untuk nilai strategi regulasi emosi pada subskala tertentu diatas nilai mean berarti regulasi emosi pada subskala tersebut sering digunakan. Sedangkan untuk pola asuh orangtua, bila skor nilai responden pada kelompok tipe pola asuh tertentu diatas nilai mean, maka pola asuh tersebut sering digunakan oleh orangtua.

\section{Hasil Penelitian}

Data karekteristik responden meliputi: usia, jenis kelamin, suku, dan kelas di sekolah. Gambaran mengenai karekteristik responden yang diteliti terlihat pada tabel 1. Berdasarkan data tersebut terlihat bahwa jumlah anak lakilaki dan perempuan berimbang, dan hampir seluruhnya berasal dari suku Sunda.

Output dari penelitian tentang regulasi emosi anak usia sekolah dengan kanker yang menjalani kemoterapi adalah diketahuinya tipe regulasi emosi secara kognitif. Tahap awal untuk mengetahui tipe regulasi emosi tersebut adalah menghitung skor total jawaban masing-masing anak pada masingmasing subskala yang terdiri dari sembilan subskala berdasarkan alat ukur kuesioner CERQ-k. Kemudian dihitung nilai mean dari masing-masing subskala tersebut, selanjutnya 
Siti Yuyun Rahayu Fitri : Strategi Regulasi Emosi Kognitif dan Pola Asuh Orangtua pada Anak

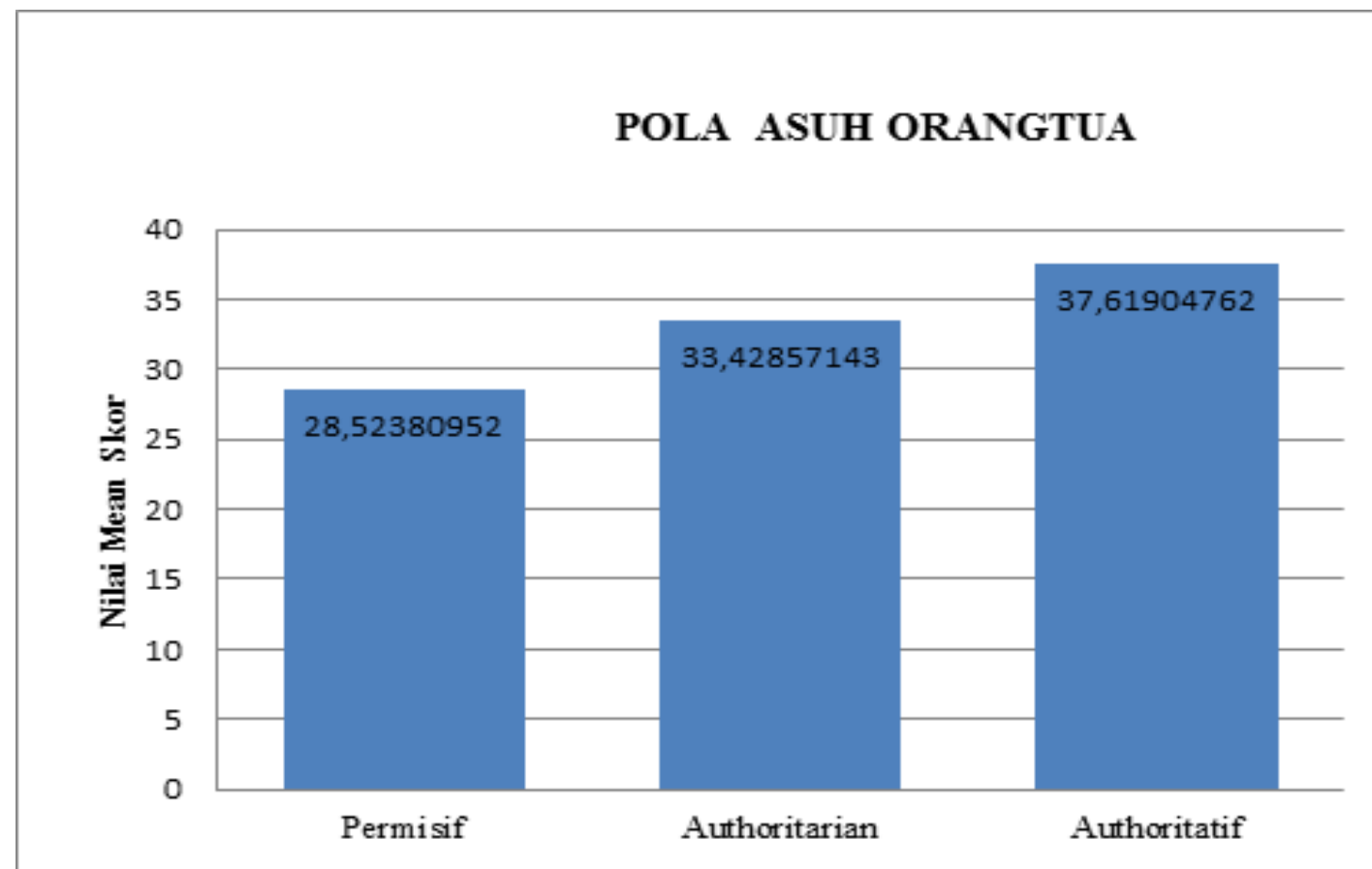

\section{Diagram 2 Rata-rata Pola Asuh Orangtua dari Anak dengan Kanker yang Menjalani Kemoterapi}

dilihat nilai rata-rata tertinggi pada masingmasing responden. Nilai rata-rata yang tinggi menunjukkan strategi regulasi emosi yang sering digunakan oleh responden. Gambaran strategi regulasi emosi pada anak dengan kanker yang menjalani kemoterapi dapat dilihat pada diagram 1 .

Berdasarkan diagram 1 dapat diketahui bahwa dari 21 anak yang diteliti, ternyata sebagian besar cenderung menggunakan strategi regulasi emosi pada tipe planning, rumination, dan putting into perspective.

Gambaran tipe pola asuh orangtua dari anak dengan kanker yang menjalani kemoterapi dapat dilihat pada diagram 2. Pada diagram 2 dapat dilihat bahwa pola asuh orangtua yang banyak diterapkan secara berturutturut adalah tipe autoritatif, autoritarian, dan permisif. Selain itu terlihat bahwa perbedaan antar tipe menunjukkan nilai yang tidak jauh berbeda. Kemudian bila dilihat secara keseluruhan, proporsi pola asuh autoritatif lebih sedikit dibanding gabungan antara autoritarian dan permisif. Autoritarian dan permisif merupakan pola asuh yang kurang efektif dibanding autoritatif. Maka secara umum pola asuh orangtua sebagian besar masih menunjukkan tipe yang kurang optimal, artinya menerapkan pola asuh otoriter.

\section{Pembahasan}

Penelitian ini dilakukan bertujuan untuk mengidentifikasi strategi regulasi emosi secara kognitif pada anak dengan kanker yang menjalani kemoterapi dan perbedaan individunya yang meliputi jenis kelamin anak dan pola asuh yang diterima dari orangtuanya. Hasil penelitian menunjukkan bahwa strategi regulasi emosi yang sering dilakukan adalah planning, rumination, dan putting into perspective. Garnefski, dkk. (2007) menyatakan bahwa planning adalah pola pikir tentang apa yang akan dilakukan dan bagaimana mengatasi peristiwa yang negatif yang menimpanya. Lalu rumination adalah berpikir tentang perasaan dan pemikiran yang berkaitan dengan peristiwa negatif, dan merenungkan apa yang dialaminya 
Siti Yuyun Rahayu Fitri : Strategi Regulasi Emosi Kognitif dan Pola Asuh Orangtua pada Anak

tersebut. Kemudian putting into perspective merupakan berpikir untuk menurunkan keseriusan peristiwa negatif yang dialami, artinya apa yang dialami relatif lebih ringan dibanding apa yang dialami orang lain. Dari tipe regulasi emosi yang sering dilakukan anak, terlihat bahwa anak sering memikirkan tentang kondisi negatif penyakitnya, namun kemudian dipikirkan pula tentang upaya untuk mengatasinya. Kemudian anak yang kemungkinan karena motivasi internal atau stimulus eksternal menganggap bahwa sakit yang dialaminya tidak lebih parah dari orang lain, artinya masih ada orang lain yang kondisinya lebih berat dari dirinya.

Banyak faktor yang dapat memengaruhi regulasi emosi yang dipilih oleh seseorang. Faktor-faktor tersebut diantaranya adalah usia (Gross, 2007; Santrock, 2008; \& Spinrad, 2007), jenis kelamin (Mc Rae, 2008), kognisi (Philippot, 2004), motivasi (Fischer dalam Philippot, 2004), aspek sosial terutama pengaruh keluarga (Thompson dan Meyer dalam Gross, 2007), budaya (Mesquita dalam Gross 2007), serta norma (Thompson dan Meyer dalam Gross, 2007).

Bila dilihat berdasarkan karekteristik responden, strategi regulasi emosi pada anak dengan jenis kelamin laki-laki dan perempuan ternyata tidak berbeda, semua sering menggunakan strategi regulasi emosi planning, rumination, dan putting into perspective. Menurut Garnefski, dkk. (2007) perempuan dan laki-laki memiliki regulasi emosi yang relatif berbeda. Menurutnya, perempuan lebih banyak melakukan rumination (terus menerus memikirkan hal yang negatif), catastrophizing (merasa peristiwa yang dialami adalah pengalaman yang buruk), dan positive refocusing (fokus pemikiran pada hal-hal positif atau menyenangkan daripada memikirkan yang sebenarnya).

Unsur budaya kemungkinan dapat berperan dalam pemilihan strategi regulasi emosi ini. Kitayama (2004) dan Matsumoto (2008) dalam penelitian cross cultural-nya menyatakan bahwa memang regulasi emosi yang dilakukan seseorang bisa terjadi dalam tataran kolektif atau individual. Akan tetapi dengan dimediasi oleh nilai subjektif dan sikap, seseorang yang berada pada kultur kolektif mempunyai dukungan interdependen yang kuat, hal ini mempunyai implikasi bahwa jika seseorang menghadapi emosi, ia akan mendekat (engagement) dan mencari dukungan sosial. Hal ini memungkinkan seseorang memiliki bentuk regulasi interpersonal yang kuat. Sebaliknya pada kultur individual atau independent, seseorang cenderung relatif menjauh (disengagement) dari peran sosial, hal ini memungkinkan seseorang lebih cenderung melakukan regulasi secara intrapersonal.

Faktor keluarga atau bisa dilihat dari tipe pola asuh yang didapatkan oleh anak, pada responden terlihat bahwa paling banyak anak mendapatkan pola asuh autoritatif, kemudian berturut-turut autoritarian dan permisif. Namun bila dibandingkan dengan gabungan jumlah skor rata-rata antara autoritarian dan permisif yang dianggap sebagai tipe pola asuh yang tidak efektif, maka tipe pola asuh autoritatif sebagai pola asuh yang dianggap optimal jumlahnya lebih kecil. Ada beberapa faktor yang memengaruhi tipe pola asuh yang dilakukan oleh orangtua diantaranya adalah status ekonomi (Brody \& Armistead, 2002; Gliebe, 2013), religiusitas (Terry, 2004), kultur (Cote, 2003 \& Chiang, 2000).

Grundman (2010) menyatakan pola asuh orangtua berpengaruh terhadap kemampuan self regulation dan emosi pada anak. Semakin baik pola asuh orangtua maka kemampuan regulasi diri (self regulation) anak semakin baik dan semakin kecil pengalaman emosi (emotion outcome) anak. Kemudian Robinson (2006) menyatakan bahwa regulasi emosi pada anak saat sekarang dipengaruhi oleh pola asuh dalam konteks masa lalu, artinya pola asuh tidak serta merta berpengaruh terhadap regulasi emosi pada anak tetapi dimediasi konteks maltreatment pada masa lalu. Dengan demikian regulasi emosi pada anak saat ini bisa pula dipengaruhi kondisi masa lalu terutama pengalaman maltreatment yang didapatkan anak.

\section{Simpulan}

Strategi regulasi emosi yang banyak dilakukan oleh anak dengan dengan kanker yang dilakukan kemoterapi adalah planning, rumination, dan putting into perspective. Anak dengan kanker yang dilakukan kemoterapi sering memikirkan pengalaman negatifnya. 
Siti Yuyun Rahayu Fitri : Strategi Regulasi Emosi Kognitif dan Pola Asuh Orangtua pada Anak

Perbedaan individu dari faktor jenis kelamin tidak terlihat, sedangkan dari faktor pola asuh terlihat bahwa mereka sebagian kecil mendapatkan pola asuh autoritatif. Sebagian besar mendapatkan pola asuh yang dianggap tidak optimal yaitu autoritarian dan permisif.

Strategi regulasi emosi yang dilakukan anak dianggap cukup optimal dan pola asuh yang didapatkan kurang efektif, hal ini dapat dimungkinkan oleh faktor budaya timur yang cenderung menunjukkan tipe kolektivisme di Indonesia. Budaya kolektivisme ini memungkinkan regulasi eksternal oleh keluarga selain orangtua.

Bagi institusi pelayanan kesehatan (rumah sakit) dan tenaga keperawatan diharapkan dapat mengidentifikasi kemampuan pasien anak dalam mengelola emosi selama dirawat saat proses kemoterapi, melibatkan orangtua atau keluarga dalam mendukung proses internalisasi regulasi emosi anak serta melakukan pendekatan dalam setiap pelayanan kepada anak yang menjalani hospitalisasi dengan mendasarkan pada kondisi psikologis anak terutama keadaan emosinya dan pola regulasi emosi yang biasa dilakukan. Sehingga anak akan merasa nyaman dan dapat menerima tindakan yang akan dilakukan dengan pendekatan yang optimal. Tenaga kesehatan, terutama perawat sebagai tenaga kesehatan yang lama berinteraksi dengan pasien, perlu melibatkan orangtua dalam meningkatkan status psikologis anak.

Orangtua khususnya seorang ibu, diharapkan mampu untuk meningkatkan dan mengoptimalkan kemampuan regulasi emosi anak. Hal ini dapat dilakukan dengan cara memberikan instruksi langsung (direct instruction), mengajukan reinterpretasi penyebab (proposals for reinterpreting the cause), memberikan model (model learning) yang baik, karena anak akan mencontoh model, dan berdiskusi seputar masalah emosi (discourse over emotions). Orangtua juga harus memberikan kesempatan bagi anak untuk mengekspresikan perasaan subjektif yang berkaitan dengan emosi secara verbal, serta mendengarkan apa yang diungkapkan tersebut.

Pada penelitian selanjutnya perlu dipertimbangkan untuk dilakukan penelitian lanjutan dengan responden yang jumlahnya lebih banyak padaberbagai rumah sakit. Selain itu, perlu juga diidentifikasi determinan pola asuh yang dilakukan orangtua seperti usia orangtua, status sosial ekonomi, dan riwayat pola asuh yang dilakukan pada masa lalu Penelitian pada anak yang sedang menjalani hospitalisasi perlu mempertimbangkan status kesehatannya secara umum, karena dalam kondisi sakit anak akan mengalami masalah kesehatan yang bervariasi.

\section{Daftar Pustaka}

Brody \& Armistead. (2002). Predicting interpersonal competence in young adulthood: The roles of family, self, \& peer systems during adolesence. Journal of Child \& Family Studies, 4(60).

Chiang, T. M, Barett, K.C., \& Nunez, N.N. (2000). Maternal attributions of Taiwanese and American toddlers' misdeeds and accomplishments. Journal Of CrossCultural Psychology 31(3), 349-368. doi: 10.1177/0022022100031003004.

Cote, L.R., \& Bornstein, M. (2003). Cultural and parenting cognitions in acculturating cultures 1, cultural comparisons and developmental and stability. Journal of Cross-Cultural Psychology, 34(3), 323-349. doi: 10.1177/0022022103034003006.

Fitri, S.Y.R., Atmodiwirji, E.T., \& Wilman, W. (2011). Emotion regulation in childhood with cancer (Acute Lymphocitic Leukemia). American Medical Journal, 2(2), pp. 79-86.

Garnefski, N., Kraaij, V., \& Spinhoven, P. (2007). Cognitive emotion regulation strategies and emotional problems in 9-11 year old children. Eur Child Adolescence Psychiatry, 16, 1-9.

Gabrieli, J.D \& Gross, J.J. (2008). Gender differences in emotion regulation: An MRI study of cognitif reappraisal. Group Process and Intergroup Relation, 11, 43-162.

Gliebe, S. K. (2013). A study of the relationship between cognitive emotion 
Siti Yuyun Rahayu Fitri : Strategi Regulasi Emosi Kognitif dan Pola Asuh Orangtua pada Anak

regulation, optimism, and perceived stress among selected teachers in lutheran schools. Southwestern Baptist Theological Seminary, $97,3535537$.

Gross, J.J. (2007). Handbook of emotion regulation. New York: The Guilford Press.

Grundman, J.K. (2010). Does parenting style predict identity and emotional outcomes in emerging adulthood. College Journal of Gustavus Undergraduate Psychology. Diakses dari https://gustavus.edu/.../ JennyGrundman.pdf.

Holodynski, M \& Fridelmeier, W. (2005). Development of emotions and their regulation, an internalization model. New York: Springer.

Jones, D.J., Forehand, R., Brody, G.H., \& Armistead, L. (2002). Positive parenting and childpsychosocial adjustment of inner-city single parent African American families: The role of optimism. Behavior Modification, 26, 464-481.

Kiecolt, J.K., Mc. Guire, L.M., Robbs, T.F., Glaser, R. (2002). Emotions, morbidity, and mortality: new perspectives from psychoneuroimmunology. Annual Reviews, 53, 85-107.

Kitayama, S., Karasawa, M. Mesquita, B. (2004). Collective and personal proceeds in regulating emotions: emotion and self in Japan and The United States. In P. Philippot, P \& R. S., Feldman (Eds.) The Regulation of Emotion. New Jersey: Lawrence Erlbaum Associates Publishers.

Martini, T. S., Root, C.A., \& Jenkins, J. M. (2004). Low and middle income mothers' regulation of negative emotion: Effects of children's temperament and situational emotional responses. Social Development, $13,4,516-529$.

Matsumoto, D., Yoo, S.H, Nakagawa, S. (2008). Culture, emotion regulation, and adjusment. Journal of Personality and Social Psychology, 94(6), 925-937.

McCaffrey, C.N. (2006). Implementation and evaluation of the modified feeling great program for oncology children. Journal of Health Education, 106.

Mc Rae, K., Oschner, K. N.,Mauss, T. B.; Middendorp, H.V., Geenen, R., Sorbi, M., Doornen, L. J. P., \& Bijlsma, J. (2005). Emotion regulation predicts change of perceived health in patients with rheumatoid arthritis. Ann Rheum Disease, 64, 1071-1074.

Middendorp, H. V., Greenen, R., \& Sorbi, M. J. (2005). Styles of emotion regulation and their association with perceived health. Ann Behavior Medicine, 30(1), 44-53.

Philippot, P. \& Feldman, RS. (2004). The regulation of emotion. New Jersey: Lawrwnce Erlbaum Associates Publishers.

Robinson, L.R. (2006). Relations between parenting, family context, and emotion regulation in the development of psychopathology in young maltreated children. (University of New Orleans Thesses and Dissertation).

Reitman, D., Rhode, P. C., Hupp, S. D. A., Altobello, C. (2002). Development and validation of parental authority questionaireresived. Journal of Psychopatologyand Behavioural, 24(2).

Salovey, P. (2001). Applied emotional intelligence: Regulating emotions to become healthy, wealthy, and wise. In J. Ciarrochi, J. Forgas, \& J.D. Mayer (Eds.), Emotional intelligence in everyday life: A scientific inquiry. Philadelphia, PA: Psychology Press.

Santrock, J.W. (2008). Life span development (11th ed.). New York: Mc Graw Hill International.

Sapolsky, R.M. (2007). Stress, stress-related disease, and emotional regulation. In Gross, JJ (Eds.), Handbook of Emotion. New York: Guilford Press.

Sarafino, E.P (2006). Health psychology biopsychosocial interactions (5th ed.). USA: John Wiley \& Sons, Inc.

Spinrad, TL; Eisenberg, N; Gaertner, BM. 
Siti Yuyun Rahayu Fitri : Strategi Regulasi Emosi Kognitif dan Pola Asuh Orangtua pada Anak

(2007). Measures of effortfull regulation for young children. Infant Mental Health Journal, 28(6): 606-626.

Terry, D. J. (2004). Investigating the relationship between parenting styles and delinquent behavior. McNair Scholars Journal, 8(1), 87-94. Diakses dari http:// scholarworks.gvsu.edu/mcnair/vol8/iss1/11. 